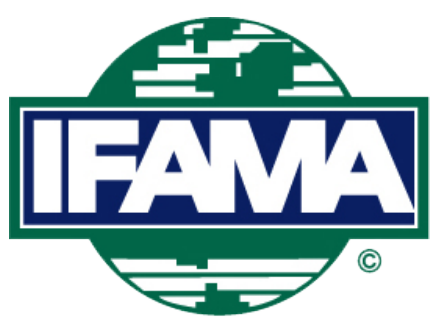

International Food and Agribusiness Management Review

Volume 23, Issue 3, 2020; DOI: 10.22434/IFAMR2019.0117

Received: 28 October 2018 / Accepted: 10 March 2020

\title{
Rice farmers' demands for productive services: evidence from Chinese farmers
}

\author{
RESEARCH ARTICLE \\ Qi $\mathrm{Li}^{\mathrm{a}}$ and $\mathrm{Kai} \mathrm{Li}^{\oplus b}$ \\ ${ }^{a}$ Lecturer, ${ }^{b}$ Associate Professor, School of Economics, Qufu Normal University, \\ 80 Yantai North Road, Rizhao, Shandong 273165, China P.R.
}

\begin{abstract}
Based on the data of 601 rice farmers in Zhejiang and Jiangsu provinces in China, we analyzed the type and intensity of farmers' demands for productive services and the factors influencing agricultural green transformation in this developing country. The results show that rice farmers most urgently demand services including plant protection information, seedling supply, and unified prevention and treatment, with lower demand for services providing information about materials and soil. Given the consistency of productive services at the village level, we used a hierarchical linear model to analyze factors influencing farmer demand. The results show that for farmers with low levels of technology adoption, their demands for the services are significantly impacted by economic development level, production areas, rice planting labor, and technical knowledge, whereas for farmers with high levels of technology adoption, village service levels and production areas significantly affect their service demands.
\end{abstract}

Keywords: productive services, green productive technologies, rice farmers, demand intensity, impact factors JEL code: D91, Q12, Q16

(1)Corresponding author: 1i-kai@fafu.edu.cn 


\section{Introduction}

As non-point source pollution is a major obstacle to maintaining the sustainability of agriculture (Atreya et al., 2012; Mariwah and Drangert, 2011; Rasmussen et al., 2015; Yin et al., 2018), it has become a top priority for agricultural restructuring in developing countries to achieve green production, which is the transformation from industrial to sustainable agriculture. Green productive technologies refer to production technology that can reduce the amount of chemical fertilizer and pesticides used, and ensure agricultural product quality and safety using harmless and pollution-free production inputs. However, the promotion of green productive technologies, such as fertilizer-reducing and straw return to the field technologies, has been largely curbed among planting farmers. Green technology extension is hindered by the following two factors according to the literature. Firstly, most green productive technologies are highly technical, which means the learning costs are high (Kabir and Rainis, 2015; Reimer et al., 2012; Teshome et al., 2016; Zhou et al., 2012). For example, farmers who have adopted fertilizer-reducing technology worry about the grain yield. Secondly, some green productive technologies are costly. The increase in production costs, especially in labor costs, may exceed the revenue from increased production, so farmers need to pay higher costs and accept a higher risk to adopt green productive technologies (Affholder et al., 2010; Anne and Olsson, 2014; Cai, 2013; Zhu and Tian, 2012). Since the problem of excessive chemical fertilizer and pesticide use is important for many farmers, the green transformation in China is facing barriers.

Dissemination of new technologies is a serious challenge for farmers in developing countries, especially for Chinese farmers who are generally older, poorly educated, and risk-averse (Liu, 2013; Mills et al., 2017; Yang et al., 2012). As such, studies have indicated the positive role of agricultural productive services in reducing the cost of green production, alleviating concerns about the uncertainty of new technology in developing countries (Emmanuel et al., 2016; Mugonola et al., 2013; Raju et al., 2015; Ye, 2015). Li et al. (2018) showed that material services significantly positively impact rice farmer adoption of labor-intensive and high-skilled technologies, whereas information services have a certain positive impact on the adoption of capital- and labor-intensive technologies. However, farmer demands for agricultural productive services vary dramatically across China. Wang et al. (2015) found farmers prefer unified provision of agricultural inputs, but Li (2015) reported that the need for provision of seeds is the highest. Some researchers stated that farmers urgently need technical guidance and agricultural machinery services (Luo et al., 2016; Xia and Jiang, 2016), whereas others insisted that financial and sales services are the highest priorities (Zhu et al., 2015). To address the imbalance and structural mismatch in service supply and demand, accurately identifying the demands of farmers is essential. However, previous studies ignored special needs during the agriculture green transformation in China.

Within the context of this agriculture green transformation, we identify which productive services are urgently needed by rice farmers and what factors drive the demand for productive services, taking Chinese rice farmers as an example to promote the green and sustainable development of agriculture and accelerate the construction of agricultural productive services industry in developing countries. China is the largest rice producer and consumer in the world. The average annual rice production and consumption account for nearly $30 \%$ of the world's total. More than $60 \%$ of the country's residents consume rice as their rations (Yang, 2017). So, the problem with excessive chemical fertilizer and pesticide application in rice production in China has become more prominent since 2000, reflected in the trend of increasing chemical fertilizer input and pesticide fees. Thus, the green transformation of the grain industry in China from the producer perspective requires further study. This study is innovative in that, firstly, the services needed by farmers were screened based on green productive technologies; secondly, the Kano model was used to accurately identify the farmers' attitudes and categories for various services; and finally, by using a hierarchical linear model (HLM), the regional economy and service supply were included in the factors that impact the demands of farmers. 


\section{Identification of productive services}

First, we sorted the productive services related to rice farmers in China considering the characteristics of and gaps between production and demand in accordance with previous studies (Li, 2015; Pang, 2006; Zhang and Ying, 2007; Zhuang et al., 2011). Secondly, we conducted a Delphi investigation with technical extension staff from Zhejiang Academy of Agricultural Sciences and in-depth interviews with local experienced farmers, and eight services suitable for the local production environment were selected including information services, material services, technical guidance services, and production process assistance (Table 1).

Table 1. Available productive services for chemical fertilizer and pesticide reduction technologies.

\begin{tabular}{|c|c|c|}
\hline Service items & Service contents and modes & Service meaning \\
\hline Supplying seedlings & $\begin{array}{l}\text { Major rice farmers and grain cooperatives } \\
\text { sign contracts with farmers to adopt unified } \\
\text { pest- and disease-resistant varieties and } \\
\text { unified seedlings for farmers in accordance } \\
\text { with standardized technical requirements. } \\
\text { Government subsidies are provided to the } \\
\text { farmers receiving and providing services. }\end{array}$ & $\begin{array}{l}\text { Promote pesticide reduction varieties, } \\
\text { reduce the costs of raising seedlings and } \\
\text { improve the quality of seedlings. }\end{array}$ \\
\hline $\begin{array}{l}\text { Technical training and } \\
\text { guidance }\end{array}$ & $\begin{array}{l}\text { Governments hold training courses on } \\
\text { chemical fertilizer and pesticide reduction, } \\
\text { and provide on-site learning; agricultural } \\
\text { technicians provide field and in-house } \\
\text { technical guidance. }\end{array}$ & $\begin{array}{l}\text { Change farmers' concepts of fertilizer } \\
\text { and pesticide application, provide farmers } \\
\text { with the channels to know, learn, and } \\
\text { master the technologies for chemical } \\
\text { fertilizer and pesticide reduction. }\end{array}$ \\
\hline $\begin{array}{l}\text { Plant protection } \\
\text { information }\end{array}$ & $\begin{array}{l}\text { Government-owned crop pest testing and } \\
\text { reporting agencies monitor, forecast, and } \\
\text { provide information about rice pests and } \\
\text { diseases. }\end{array}$ & $\begin{array}{l}\text { Standardize farmer pesticide application } \\
\text { practices, reduce application times and } \\
\text { improve the effectiveness of pesticide } \\
\text { reduction technologies. }\end{array}$ \\
\hline $\begin{array}{l}\text { Soil testing } \\
\text { information }\end{array}$ & $\begin{array}{l}\text { Government staff in agro-technology } \\
\text { extension collect and analyze the soil nutrients } \\
\text { in the region, develop soil testing formulas, } \\
\text { and distribute a card suggesting the formula } \\
\text { and fertilization to farmers. }\end{array}$ & $\begin{array}{l}\text { Help adjust farmer fertilization structure, } \\
\text { reduce unnecessary input of fertilizers, } \\
\text { and improve fertilizer application } \\
\text { efficiency. }\end{array}$ \\
\hline $\begin{array}{l}\text { Market information } \\
\text { about agricultural } \\
\text { methods of production }\end{array}$ & $\begin{array}{l}\text { Government departments provide farmers } \\
\text { with market information about purchasing } \\
\text { channels, marketing prices, quality varieties, } \\
\text { pesticides, and fertilizers. }\end{array}$ & $\begin{array}{l}\text { Promote high quality chemical fertilizers } \\
\text { and pesticides, reduce the costs of farmers } \\
\text { in searching. }\end{array}$ \\
\hline Subsidized farm inputs & $\begin{array}{l}\text { Governments purchase high-quality } \\
\text { pesticides, chemical fertilizers, and organic } \\
\text { fertilizers through unified bidding to subsidize } \\
\text { in price for farmers. }\end{array}$ & $\begin{array}{l}\text { Secure preferential prices, block fake and } \\
\text { poor quality agricultural commodities } \\
\text { from entering the market at source to } \\
\text { ensure the quality of agricultural products. }\end{array}$ \\
\hline Free farm inputs & $\begin{array}{l}\text { Governments provide free to farmers: vetiver, } \\
\text { sunflowers, sesame seeds, etc. }\end{array}$ & $\begin{array}{l}\text { Reduce the costs of farmers when } \\
\text { adopting technologies. }\end{array}$ \\
\hline $\begin{array}{l}\text { Unified prevention and } \\
\text { control }\end{array}$ & $\begin{array}{l}\text { Major farmers, grain cooperatives, or } \\
\text { professional plant protection organizations } \\
\text { sign contracts with farmers to set up } \\
\text { prevention teams to provide contract services } \\
\text { integrating green prevention and control } \\
\text { technologies. Government subsidies provided } \\
\text { to farmers receiving and providing services. }\end{array}$ & $\begin{array}{l}\text { Reduce the costs of plant protection for } \\
\text { farmers, improve the quality of plant } \\
\text { protection, and increase the use of green } \\
\text { control technologies. }\end{array}$ \\
\hline
\end{tabular}


These eight productive services provide the fundamental and inclusive services for agricultural information and technical training upon which green productive technologies depend, enabling farmers to take action. The services improve the production quality and efficiency of rice seedling growth and plant protection, allowing farmers to achieve quality production, which is conducive for farmers to learn, absorb, and practice green productive technologies. Given the strong positive externality, the productive services need to be provided by the governments or quasi-government departments, which can exercise their power to directly provide public welfare services and to purchase productive services from professional service companies, farmer cooperatives, professional service teams, and other business service organizations through government orders and direct commissions.

\section{Analysis of the demands for productive services based on Kano model}

\subsection{Study area and data sources}

The data in this study were obtained from an investigation of rice farmers in Zhejiang and Jiangsu provinces in China from July to September 2017. We selected these two provinces because incorporated the concept of green development earlier and positively promoted the construction of productive services industry, which means the household survey data from Zhejiang and Jiangsu would more accurately summarize farmer demand for productive services in the context of green agricultural transformation.

Households were randomly selected based on multi-stage cluster sampling. In the first stage, we chose six counties in Zhejiang and two counties in Jiangsu that were the first promote green productive technologies. In every county, 6-9 villages were randomly selected, for a total of 51 villages. Then, 10-13 households were randomly selected in each of the villages. The survey was conducted one-to-one for with a total of 638 questionnaires, of which 601 were valid, with a response rate of $94.20 \%$.

\subsection{Research methods}

In previous studies, descriptive analysis is the most common method used to measure farmer demand for productive services, ranking the demand intensity of farmers for services using preferred or weighted frequency (Li, 2015; Wang et al., 2007; Zhuang et al., 2011). However, the ranking results of the descriptive analysis are not always robust and may not reflect the characteristics of farmer demand for different services.

The Kano model, originally proposed on the basis of Hertzberg's two-factor theory, has been widely applied as an effective tool for identifying individual preferences by simultaneously revealing customer preferences, requirement prioritization, and requirement classification (Xu et al., 2009). Studies have reported an upward trend in adopting the Kano model to improve product quality to meet individual demand (Chen and Chuang, 2008; Luor et al., 2015; Mikulić and Prebežac, 2011; Tontini, 2007; Zhao and Roy, 2009). Liu (2015) and Zhang et al. (2017) effectively applied the Kano model to analyze farmer demand for productive services, and drew several applicable conclusions. They reported that compared to traditional classification methods, the Kano model identifies the main factors affecting customer satisfaction through mining the potential demands of users (Pan et al., 2016), so the model could effectively identify farmers' attitudes towards specific productive services and prioritize their service demands (Liu, 2015; Zhang et al., 2017).

Therefore, we used the Kano model to examine farmers' attitudes toward services by providing their own approach to classifying productive services using a structured questionnaire consisting of pairs of questions for each given service and each answer pair was aligned with a special Kano evaluation table, allowing us to classify the attitudes of each respondent and the demand of rice farmers for material services (Kano et al., 1984). According to the Kano evaluation table, the rice farmers' demands for productive services can be classified into five groups (Table 2). The frequencies of single-respondent categorizations are used to produce the final classification of services (Mikulić and Prebežac, 2011). 
Table 2. Explanation of the five classifications of the Kano model.

\begin{tabular}{ll}
\hline Classifications & Explanation \\
\hline Basic quality & Farmers are indignant if governments do not provide this service. \\
Performance quality & The more governments provide this service, the more satisfied the farmers. \\
Excitement quality & Farmers are happy when the service is provided but will not complain if it is not provided. \\
Indifferent quality & Farmers do not care about this service. \\
Reverse quality & Farmers will be resentful if governments provide this service. \\
\hline
\end{tabular}

After identifying the categories of demands for each service, the satisfaction of each service was then evaluated according to the Better-Worse coefficient proposed by Berger (1993). The better coefficient $\left(C_{\text {Better }}\right)$ refers to the enhanced satisfaction of farmers when receiving a service, usually positive. The closer the coefficient to 1 , the more satisfied the farmers. The worse coefficient $\left(C_{\text {Worse }}\right)$ refers to the dissatisfaction of farmers' when failing to receive a certain service, which is usually negative. The closer the coefficient to -1 , the more dissatisfied the farmers. The better-worse coefficient is the difference between the two.

$$
\begin{aligned}
& C_{\text {Better }}=\frac{\left[P_{E}+P_{P}\right]}{\left[P_{E}+P_{P}+P_{I}+P_{B}\right]} \\
& C_{\text {Worse }}=-\frac{\left[P_{P}+P_{B}\right]}{\left[P_{E}+P_{P}+P_{I}+P_{B}\right]} \\
& C_{B-W}=C_{\text {Better }}-C_{\text {Worse }}
\end{aligned}
$$

where $P_{E}, P_{P}, P_{I}$ and $P_{B}$ refer to the number of times a certain type of demand appears in all farmers for excitement, performance, indifferent, and basic services, respectively.

\subsection{Model results and analysis}

In the Kano model, single-respondent frequencies are usually used as the classification standard (Mikulic and Prebežac, 2011). Table 3 lists the classification of the productive services. A unified supply of seedlings, unified prevention and control, and free farm inputs are classified as excitement quality services, indicating that farmers are expecting these services, and but it is also acceptable if such services are not provided. Under the traditional self-sufficient production mode, seedling and prevention have always been key aspects of farm production operations. However, with the aging of family labor forces and the maturing of the agricultural productive service market, farmers are gradually becoming aware of the significant value of the supply of seedlings as well as unified prevention and treatment services, which explains why farmers are excited about these two types of services (Chen et al., 2018; Li et al., 2018). Agro-technology training and guidance and plant protection information are classified as performance quality services. Access to these services will increase the satisfaction of farmers, and the absence of these services will cause dissatisfaction. The agrotechnology training and guidance service is ranked first in farmers' demands in related studies, proving that farmers' expectations for the service are high to a certain extent (Kong and Zen, 2010; Xiong, 2010). Plant protection information is a typical public service that is classified as an expectation service. Information about soil testing, market information about agricultural methods of production, and subsidized farm inputs are services of indifferent quality. Farmers will not indicate obvious satisfaction or dissatisfaction with or without access to services. Small farmers in China are still accustomed to buying agricultural products in a market and relying on the advice of agricultural retailers rather than receiving help from social services (Sun and Huang, 2009; Zhang and Li, 2014), so services about agricultural production methods are not very attractive to farmers. In some services, little difference exists between the number of people who chose the first and second best service, so it would be inaccurate to define a service as a specific classification. To solve this problem, the better-worse coefficient was used to more accurately prioritize farmer demands for productive services. 
Table 3. Results of the classification of productive service demands.

\begin{tabular}{|c|c|c|c|c|c|c|}
\hline Service items & $\begin{array}{l}\text { Basic } \\
\text { quality }\end{array}$ & $\begin{array}{l}\text { Excitement } \\
\text { quality }\end{array}$ & $\begin{array}{l}\text { Performance } \\
\text { quality }\end{array}$ & $\begin{array}{l}\text { Indifferent } \\
\text { quality }\end{array}$ & $\begin{array}{l}\text { Reverse } \\
\text { quality }\end{array}$ & $\begin{array}{l}\text { Final quality } \\
\text { results }\end{array}$ \\
\hline Supplying seedlings & 54 & 233 & 187 & 126 & 1 & excitement \\
\hline $\begin{array}{l}\text { Technical training and } \\
\text { guidance }\end{array}$ & 125 & 157 & 182 & 134 & 3 & performance \\
\hline Plant protection information & 83 & 180 & 209 & 129 & 0 & performance \\
\hline Soil testing information & 52 & 166 & 99 & 281 & 3 & indifferent \\
\hline $\begin{array}{l}\text { Market information about } \\
\text { agricultural methods of } \\
\text { production }\end{array}$ & 47 & 172 & 108 & 270 & 4 & indifferent \\
\hline Subsidized farm inputs & 54 & 205 & 113 & 228 & 1 & indifferent \\
\hline $\begin{array}{l}\text { Unified prevention and } \\
\text { control }\end{array}$ & 41 & 238 & 197 & 125 & 0 & excitement \\
\hline Free farm inputs & 61 & 223 & 152 & 165 & 0 & excitement \\
\hline
\end{tabular}

The order of better-worse coefficients for productive services is provided in Table 4 . The first three services that rice farmers demand are plant protection information, supply of seedlings, and unified prevention and control, all with better-worse coefficients exceeding 1.100. As plant protection is technical, the difficulty in understanding the timing of prevention and control methods result in poor prevention and control effects and high labor cost; therefore, farmers rely on the information about pest and disease outbreaks provided by the government to adjust the timing and applications of pesticides and the prevention and control services to reduce plant protection inputs and improve the quality of plant protection. The same are applied to raising seedlings as the cost of a complete process of raising seedlings can be as high as RMB $100 \mathrm{yuan} / \mathrm{mu}^{1}$ or more, and poor mastery of seedling time and technology will result in rice seedlings freezing or burning. Farmers expect to improve the quality of their seedlings and the seedling survival rate with professional services. Compared with plant protection and seedling raising services, farmer demand for technical training is low as many farmers take the technical training provided by the government for granted.

The demand of rice farmers for material services, including free farm inputs and subsidized farm inputs, is lower than their demand for plant protection, seedling raising, and technical training services, mainly because farmers have access to various channels with the growing market for agricultural methods of production. In addition to unified purchasing, farmers can easily access materials through factory outlets and chain stores. Rice farmers did respond positively to the services providing information about agricultural methods

$11 m u=0.067$ ha.

Table 4. Better-worse coefficients and their ranking for different supporting services.

\begin{tabular}{lllll}
\hline Service items & $\begin{array}{l}\text { Better } \\
\text { coefficients }\end{array}$ & $\begin{array}{l}\text { Worse } \\
\text { coefficients }\end{array}$ & $\begin{array}{l}\text { Better- } \\
\text { worse }\end{array}$ & Rank \\
\hline Plant protection information & 0.647 & -0.486 & 1.133 & 1 \\
Unified prevention and control & 0.724 & -0.396 & 1.120 & 2 \\
Seedlings supply & 0.700 & -0.402 & 1.102 & 3 \\
Technical training and guidance & 0.567 & -0.513 & 1.080 & 4 \\
Free farm inputs & 0.624 & -0.354 & 0.978 & 5 \\
Subsidized farm inputs & 0.530 & -0.278 & 0.808 & 6 \\
Market information about agricultural methods of production & 0.469 & -0.260 & 0.729 & 7 \\
Soil testing information & 0.443 & -0.253 & 0.696 & 8 \\
\hline
\end{tabular}


of production and soil testing. In particular, their response to the information services of soil testing was the lowest because farmers do not have a clear idea about the benefits of adjusting fertilization structure; secondly, soil testing and fertilization formulating technologies incur high soil testing costs and highlight the poor performance of the formula fertilizers. Compared with previous studies, the classification and ranking results of the Kano model revealed that the farmer demand for material services emphasized in previous studies (Zhang and Jiang, 2015; Zhuang et al., 2011) is not very strong, and they prefer services that help with the production process, which indicates that simplifying the production process is the most beneficial to rice farmers in China due to the increase in labor costs.

\section{Analysis of factors impacting demands for productive services based on hierarchical linear model}

Based on the analysis of farmers' demands for productive service using the Kano model, we used the HLM to analyze the factors affecting farmers' demand attitudes with farmers' demands as the dependent variables.

\subsection{Research methods and model building}

Data with structural hierarchy and nesting characteristics are common in the empirical analysis of social sciences. The household data used in this study had certain nesting characteristics and hierarchical structure, which were nested in the village, just like a student is nested in classes. Firstly, data were randomly selected based on a multi-stage cluster sampling. Secondly, productive service needs of farmers were subject to the situation in their own villages in addition to individual factors. Farmers of the same village have the same production environment, background, and policy characteristics, which cause a group effect or background effect. However, using the general linear regression model without considering factors at the village level results in the omission of a shared group effect or background effect and violates the basic assumption that the residual of the linear regression model is independent. The HLM, also known as multilevel modeling, proposed by Lindley and Smith in 1972, was specifically designed to analyze data with structural hierarchy and nesting characteristics by decomposing the traditional linear model random variation into intra-group variation and inter-group variation which effectively distinguishes the influence between individual or group factors.

The HLM has been used in the fields of education, psychology, and others as an effective tool to manage individual-level data that are collected within groups, solving the problem that had puzzled the statistical community for a long time (Ciarleglio and Makuch, 2007; Gelman, 2006; Kim and Kim, 2006; Rachael, 2012; Rocconi, 2013; Soukup, 2006; Walters and Hoffman, 2017).

The application of the HLM in the field of agricultural economy has been gradually increased. Since agricultural survey data usually have a hierarchical structure, using a multi-level method is more suitable for analyzing the behavior of farmers participating in training, production, and other activities (Gao et al., 2017; Liu et al., 2014; Yueh et al., 2013). However, few studies on the demand for productive services have considered this method. Researchers used the ordinary least square model or a logistic model, which require the independence assumption to explain the factors affecting the service demand of farmers from individual factors (Ghiasi et al., 2017; Wang et al., 2015; Xu and Ying, 2015), thus ignoring the common background of villages and reducing the power of the statistical analysis (Teo, 2011). As such, we used the HLM to explore the factors impacting farmer demands for productive services from two levels: villages and farming households.

The HLM consists of two parts: the null model and the complete model. In each part, the intercept and slope of the first level are taken as the dependent variables of the second level regression, and the independent variables of the second level are analyzed by regression. In the null model, no explanatory variables are added to the model and the total variance of individuals is decomposed into intra-group variation from the same group, and inter-group variation from different groups to determine whether each level has a significant effect on 
the dependent variables. The complete model, including all the impact factors at the first and second levels, checks the impacts of the independent variables at the two levels and the cross-level interaction. Equations 4-12 outline the specific models. The basic null model includes two levels. The first-level model is:

$$
\begin{aligned}
& Y_{i j}=\beta_{0 j}+r_{i j} \\
& \operatorname{Var}\left(r_{i}\right)=\sigma^{2}
\end{aligned}
$$

The second-level model:

$$
\begin{aligned}
& \beta_{0 j}=\gamma_{00}+u_{0 j} \\
& \operatorname{Var}\left(u_{0 j}\right)=\tau_{00}
\end{aligned}
$$

The two levels of models of the basic complete model are, for the first level:

$$
Y_{i j}=\beta_{0 j}+\beta_{1 j} X_{1 i j}+r_{i j}
$$

and, for the second-level model:

$$
\begin{aligned}
& \beta_{0 j}=\gamma_{00}+\gamma_{01} W_{1 j}+u_{0 j} \\
& \beta_{1 j}=\gamma_{10}+\gamma_{11} W_{1 j}+u_{1 j} \\
& \operatorname{Var}\left(u_{0 j}\right)=\tau_{00} \\
& \operatorname{Var}\left(u_{1 j}\right)=\tau_{10}
\end{aligned}
$$

Where $Y_{i j}$ represents the dependent variable, $\beta_{0 j}$ is the first-level intercept term, $\beta_{1 j}$ is the first-level slope term, $r_{i j}$ is the first-level residual term., $\gamma_{00}$ is the second-level intercept term of Equation $9, \gamma_{01}$ is the second-level slope term of Equation 9, $u_{0 j}$ is the second-level residual term of Equation 9, $\gamma_{10}$ is the second-level intercept term of Equation 10, $\gamma_{11}$ is the second-level slope term of Equation 10, $u_{1 j}$ is the second-level residual term of Equation 10, $X_{1 i j}$ are the first-level dependent variables, and $W_{1 j}$ are the second-level independent variables.

\subsection{Variable selection and descriptive analysis}

With reference to Zhang et al. (2017), we used the total numbers of basic and performance services from Section 3.3 to represent the intensity of service demands of farmers. Based on previous reports (Kallas et al., 2010; Kibwika et al., 2009; Li and Jiang, 2015; Li and Zhang, 2011; Tan et al., 2017), the household-level variables included production areas, household labor, production experience, multiple family businesses, the cost of rice production, and farmers' understanding of technical difficulties. The village-level variables included the level of economic development and the availability of productive services, represented by average employment prices and the number of services provided locally, respectively. Table 4 lists the specific variables. The comprehensive model of empirical analysis is expressed as:

$$
\begin{aligned}
\text { Nec }= & \gamma_{0}+\gamma_{01} \text { Pri }+\gamma_{02} \text { Avai }+\gamma_{10} \text { Year }+\gamma_{20} \text { Area }+\gamma_{30} \text { Cost }+\gamma_{40} \text { Lab }+\gamma_{50} \text { Bus }+ \\
& \gamma_{60} \text { Reg }+\gamma_{61} \text { Avai } \times \text { Reg }+u_{0}+r
\end{aligned}
$$

The source of the data used by the HLM model was the same as in Section 3.1. From the results of the descriptive analysis (Table 5), we found the average demand intensity of sampling farmers was 2.93 , with an average of three types of basic or performance services out of the eight types of services. The overall demand for services was not high, partly because the farmers do not have many expectations about productive 
Table 5. Variable description and descriptive analysis.

\begin{tabular}{|c|c|c|c|c|}
\hline Variable & Description & Unit & Average & Variance \\
\hline Demand intensity $(\mathrm{Nec})$ & $\begin{array}{l}\text { Total numbers of basic and } \\
\text { performance services }\end{array}$ & number & 2.93 & 1.78 \\
\hline \multicolumn{5}{|l|}{ Farming household level } \\
\hline Production experience (Year) & $\begin{array}{l}\text { Years of rice planting of } \\
\text { family decision-makers }\end{array}$ & year & 25.50 & 16.13 \\
\hline Production area (Area) & Rice planting areas & $\mathrm{mu}$ & 64.18 & 112.25 \\
\hline Production cost (Cost) & Rice production costs & yuan $/ \mathrm{mu} \cdot$ season & 990.06 & 461.54 \\
\hline Rice planting labor $(L a b)$ & Rice planting labor & person & 2.96 & 1.37 \\
\hline Multiple family business (Bus) & $\begin{array}{l}\text { Proportion of non-farming } \\
\text { income in total family income }\end{array}$ & $\%$ & 37.90 & 32.16 \\
\hline Technical cognition (Reg) & $\begin{array}{l}\text { Whether green productive } \\
\text { technologies are difficult }\end{array}$ & $\begin{array}{l}0=\text { no } \\
1=\text { yes }\end{array}$ & 0.23 & 0.42 \\
\hline \multicolumn{5}{|l|}{ Village level } \\
\hline Economic development level (Pri) & $\begin{array}{l}\text { Average employment prices } \\
\text { in the region }\end{array}$ & yuan/working day & 122.04 & 56.87 \\
\hline Availability of services (Avai) & $\begin{array}{l}\text { No. of productive services } \\
\text { provided locally }\end{array}$ & items & 3.36 & 1.50 \\
\hline
\end{tabular}

services and partly because they are accustomed to a long-term self-sufficient mode of production. Farmers have rich production experience and large production areas, and paddy rice is no longer the only source of income for most farmers. The average cost of planting rice is close to $1000 \mathrm{yuan} / \mathrm{mu}$ with an average labor cost of 122 yuan/mu. Only $23 \%$ of the farmers think it difficult to master green productive technologies, indicating technical difficulty is not preventing the majority of farmers from achieving green production.

\subsection{Model results and analysis}

The samples were divided into high-level and low-level green productive technology adoption groups to analyze the heterogeneity of farmer demands for services. The grouping criteria were the adoption scores of the sample farmers for green productive technologies in rice. A sample farmers' adoption score is the sum of scores of 11 popular green productive technologies in rice with technical complexity as weight. Farmers above the average score were grouped into the high-level technology adoption group; those below the average were grouped into the low-level technology adoption group. HLM was evaluated using HLM 7.0 software (Scientific Software International (SSI)). According to the idea introduced by Hofmann (1997), the null model is first applied to analyze the impacts of service demands on farming household and village levels, and then the complete model is applied to analyze the impacts of each independent variable on service demands. To further clarify the impact of village service availability, the service availability variable was placed on the slope of the second-level technical understanding for estimation.

\section{Null model estimation results}

The null model estimation results are provided in Table 6. Firstly, the correlation coefficient $\rho$ (intraclass correlation coefficient) was calculated for the variance variation at the village and the farming household levels, and the $P$-values for the low-level and the high-level technology adoption groups were 0.38 and 0.61 , respectively, indicating that 38 and $61 \%$ of the total service demand variations of rice farmers were from the village level, respectively, which is highly relevant (Cohen, 1988) $)^{2}$. So, village-level differences cannot be

\footnotetext{
${ }^{2}$ According to Cohen's classification, $0.01 \leq P<0.059$ is a weak relationship; $0.059 \leq P<0.138$ is a moderate relationship, and $P \geq 0.138$ is a strong relationship.
} 
Table 6. Null model estimation results. ${ }^{1}$

\begin{tabular}{|c|c|c|c|c|c|c|}
\hline \multirow[t]{2}{*}{ Variable hierarchy } & \multicolumn{3}{|c|}{ Low-level technology adoption group } & \multicolumn{3}{|c|}{ High-level technology adoption group } \\
\hline & Variance & SD & $P$-value & Variance & SD & $P$-value \\
\hline Village level $\left(\tau_{00}\right)$ & 0.9760 & 0.9879 & $0.000^{* * *}$ & 1.9577 & 1.3992 & $0.000^{* * *}$ \\
\hline Farming household level $\left(\sigma^{2}\right)$ & 1.6566 & 1.2871 & & 1.2837 & 1.1330 & \\
\hline
\end{tabular}

${ }^{* * * *}$ indicates significance at $1 \%$ level; $\mathrm{SD}=$ standard deviation.

ignored. $P$-values were all 0.000 , ands if the original hypothesis is rejected, the village-level variables have a significant impact on service demands. In summary, the data, with a hierarchical structure, were suitable for estimation using HLM.

\section{- Complete model estimation results}

The complete model estimation results are shown in Table 7. According to the estimation results of the lowlevel technology adoption group, from the village level, economic development level had a positive impact on the service demand at $1 \%$ significant, indicating that the higher the economic development, the stronger the demands for services. Because land and labor costs tend to be high in the areas with a stronger economy, rice planting depends more on services and subsidies. The impact of service availability was positive but not significant, probably because the farmers in the low-level technology adoption group are less concerned about service-related policies or regulations. From a household level, compared with the farmers who think that green productive technologies are easy to learn, the demands for services that farmers find technically difficult are even stronger at the 5\% significance. If farmers think they are less able to acquire the relevant technologies, they tend to rely on productive services to help themselves. Both production costs and production areas had positive impacts at the $1 \%$ level as farmers rely more on productive services due to the increased difficulty of applying green productive technologies. Likewise, the farming workforce, i.e. the difficulties due to workforce shortages, also had a positive impact at the $1 \%$ level. The positive correlation coefficient between technical cognition and service availability indicates that in the areas with high service availability, farmers tend to seek help from services if they think the technologies are harder to learn. However, farmers tend to solve the problems on their own in areas with low service availability.

Table 7. Complete model estimation results.

\begin{tabular}{|c|c|c|c|c|c|c|}
\hline \multirow[t]{2}{*}{ Variable } & \multicolumn{3}{|c|}{ Low-level technology adoption group } & \multicolumn{3}{|c|}{ High-level technology adoption group } \\
\hline & Coefficient & SD & $P$-value & Coefficient & SD & $P$-value \\
\hline Intercept & 0.8465 & 0.6308 & 0.194 & $1.4803^{* *}$ & 0.7015 & 0.048 \\
\hline \multicolumn{7}{|l|}{ Village level } \\
\hline Economic development level & $0.0102^{* * *}$ & 0.0036 & 0.010 & $0.0098^{*}$ & 0.0053 & 0.080 \\
\hline Service availability & 0.0851 & 0.1078 & 0.439 & $0.3695^{* *}$ & 0.1748 & 0.048 \\
\hline \multicolumn{7}{|l|}{ Farming household level } \\
\hline Green technical cognition & $1.2050^{* *}$ & 0.4996 & 0.017 & $2.3374^{*}$ & 1.3083 & 0.075 \\
\hline Multiple family business & -0.0034 & 0.0027 & 0.204 & -0.0024 & 0.0024 & 0.315 \\
\hline Production experience & 0.0019 & 0.0040 & 0.641 & -0.0008 & 0.0049 & 0.875 \\
\hline Production cost & $0.0007^{* * *}$ & 0.0002 & 0.003 & 0.0001 & 0.0002 & 0.796 \\
\hline Rice planting labor & $-0.1524^{* *}$ & 0.0750 & 0.043 & -0.0295 & 0.0504 & 0.558 \\
\hline Production areas & $0.0048^{* * *}$ & 0.0008 & 0.000 & $-0.0014^{* * *}$ & 0.0004 & 0.002 \\
\hline $\begin{array}{l}\text { Technical cognition and } \\
\text { service availability }\end{array}$ & 0.0427 & 0.1607 & 0.791 & 0.0551 & 0.2801 & 0.844 \\
\hline Sample numbers & & 353 & & & 248 & \\
\hline
\end{tabular}

$1^{*},{ }^{* *},{ }^{* * *}$ indicate significance at 10,5 and $1 \%$ levels, respectively; $\mathrm{SD}=$ standard deviation. 
According to the estimation results for the high-level technology adoption group, from the village level, the significant impact of economic development level on service demands decreased to $10 \%$, whereas the impact of service availability was significantly positive at $5 \%$. Farmers pay more attention to the government's service policies and methods if they adopt more green productive technologies. The satisfaction with services also increases once the service availability is relatively high. From a household level, green productive technological understanding is only significant at the $10 \%$ level, indicating the service demands of some farmers do not significantly decrease although they think the technologies are easy. The impact of production inputs on service demands was weak, probably because the farmers with high-level technology adoption are more likely to consider service demands based on technologies rather than on their production endowment. The impact of production areas on service demands was significantly negative at the $1 \%$ level. Among the farmers in the high-level technology adoption group, the larger the production areas, the stronger their green production abilities, which means they have more suitable supporting facilities and more access to channels of information. Therefore, they have low demands for external services, which partly explains why the impacts of production costs and labor force were insignificant. For the farmers in the low-level technology adoption group, the larger the production areas, the greater their demand for external services due to imperfect supporting facilities. The interaction coefficient of technology understanding and service availability was also positive. When the service availability is high and the technologies are difficult, the farmers tend to apply the technologies with the services provided.

Compared with previous studies, the HLM results revealed that group factors, especially service availability and economic development level, impact farmers' productive service needs, indicating that only analyzing the demand of farmers for services from the individual level is insufficient. The results showed that farmers with different technology adoption levels have different service demands, which deserve the attention of policymakers.

\section{Conclusions and implications}

Providing farmers with the productive services they need for green agriculture transformation is crucial for the expansion of the use of green production technologies and the achievement of agriculture sustainability. Therefore, based on the data of 601 rice farmers in Zhejiang and Jiangsu provinces, we analyzed the type and intensity of farmer demands for productive services in the context of agriculture green transformation based on the Kano model, and analyzed the factors that impact the service demands using the HLM. The main conclusions are as follows: First, among the productive services, the farmers most need plant protection information, unified prevention and control, and seedling supply services, whereas their demands are lowest for information about agricultural methods of production and soil testing services. Second, labor costs at the village level, production area, laborer numbers, and difficulty in understanding green technology at a household level significantly affected farmers' demand in the group with a low level of green productive technology adoption. Service availability at the village level and production area at the household level had significant effects on farmer demand in the high-level green productive technology adoption group.

Additional in-depth discussions provided conclusions to gain further insight for policy makers and managers of agricultural productive service industries. Firstly, compared with material services and information services, farmers prefer productive services that can save labor input, which conforms to the labor shortages caused by the outflow of agricultural labor in China. Therefore, the government should prioritize providing unified prevention and control and seedling supply services to farmers, and improve the coverage and service capacity of these two services. Secondly, village level factors impact the service demand of farmers, which was ignored in previous studies. Therefore, we recommend establishing village service teams and formulating targeted incentive policies separately for farmers with different levels of technology adoption. These measurements will not only ensure that the service can be provided according to the situation in each village, but also expand the scale of plant protection of cooperatives and firms. Finally, considering the externalities of green production, a specialized division of productive services should be created between 
the government and commercial service organizations to balance meeting farmers' various demands and achieving economies of scale.

The findings highlight the differences between the demands for various services; however, the interdependence of different services was not incorporated into the analytical framework, so subsequent studies can further analyze the alternative or complementary relationships between services. Based on a clear understanding of service demands, future studies should integrate the supply and demand for productive services, and outline the content in different services, supply methods, and price combinations to farmers to determine their selection through the choice experiments (CE) and other methods to help develop the productive services industry in China.

\section{Acknowledgements}

This work was supported by The National Social Science Fund of China (Project Grant No. 19CGL035)

\section{References}

Affholder F., D. Jourdain, D.D. Quang, T.P. Tuong, M. Morize and A. Ricome. 2010. Constraints to farmers' adoption of direct-seeding mulch-based cropping systems: A farm scale modeling approach applied to the mountainous slopes of Vietnam. Agricultural Systems 103: 51-62.

Anne, J. and L. Olsson. 2014. Food first! Theorising assets and actors in agroforestry: risk evaders, opportunity seekers and 'the food imperative' in sub-Saharan Africa. International Journal of Agricultural Sustainability 12(1): 1-22.

Atreya, K., F.H. Johnsen and B.K. Sitaula. 2012. Health and environmental costs of pesticide use in vegetable farming in Nepal. Environment Development and Sustainability 14: 477-499.

Berger, C. 1993. Kano's methods for understanding customer - defined quality. Center for Quality Management Journal 4: 3-36.

Cai, S.K. 2013. Empirical study of economic structure, land's feature and green pest control technique adoption: based on the Anhui Province 740 rice farmer's research. Journal of China Agricultural University 4: 208-215.

Chen, C.C. and M.C. Chuang. 2008. Integrating the Kano model into a robust design approach to enhance customer satisfaction with product design. Production Economics 114: 667-681.

Chen, H., H. Zhou and X.Y. Lv. 2018. Analysis of farmers' adoption of regional pest control program - based on empirical analysis of Jiangsu. Journal of Northwest A\&F University 5(18): 104-111.

Ciarleglio, M.M. and R.W. Makuch. 2007. Hierarchical linear modeling: an overview. Child Abuse \& Neglect 2(31): 91-98.

Cohen, J. 1988. Statistical power analysis for the behavioral sciences. Academic Press, New York, NY, USA.

Emmanuel, D., E. Owusu-Sekyere and V. Owusu. 2016. Impact of agricultural extension service on adoption of chemical fertilizer: implications for rice productivity and development in Ghana. NJAS - Wageningen Journal of Life Sciences 79: 41-49.

Gao, Y., X. Zhang, L. Wu, S.J. Yin and J. Lu. 2017. Resource basis, ecosystem and growth of grain family farm in China: based on rough set theory and hierarchical linear model. Agricultural Systems 154: 137-167.

Gelman, A. 2006. Multilevel (hierarchical) modeling: what it can and cannot do. Technometrics 3(48): 432-435.

Ghiasi, R., M.S. Allahyari, C.A. Damalas, J. Azizi and M. Abedi. 2017. Crop protection services by plant clinics in Iran: an evaluation through rice farmers' satisfaction. Crop Protection 98: 191-197.

Hofmann, D.A. 1997. An overview of the logic and rational of hierarchical linear models. Journal of Management 6: 723-744.

Kabir, M.H. and R. Rainis. 2015. Adoption and intensity of integrated pest management (IPM) vegetable farming in Bangladesh: an approach to sustainable agricultural development. Environment, Development and Sustainability 17(6): 1413-1429. 
Kallas, Z., K.T. Serra and J.M. Gil. 2010. Farmers' objectives as determinants of organic farming adoption: the case of Catalonian vineyard production. Agricultural Economics 5(41): 409-423.

Kano, N., N. Seraku, F. Takahashi and S. Tsuji. 1984. Attractive quality and must-be quality. The Journal of Japanese Society for Quality Control 2: 39-48.

Kibwika, P., A.E.J. Wals and M.G. Nassuna-Musoke. 2009. Competence challenges of demand-led agricultural research and extension in Uganda. Journal of Agricultural Education \& Extension 15(1): 5-19.

Kim, J.Y. and J.H. Kim. 2006. Analysis of neighborhood effect on land price using hierarchical linear model. Korea Planners Association 5(41): 3-3.

Kong, X.Z. and Z.Y. Zhen. 2010. Research on supply and demand of agricultural socialization service analysis of farmers' data based on supply subject and demand intensity. Guangxi Social Sciences 3: $120-125$.

Li, L.F., L.Z. Ying and X.M. Zhan. 2018. Study on the driving force of agricultural division of labor and socialization of production: analysis of outsourcing behavior of rice seedling of farmers. Rural Economy 2: 86-91.

Li, Q. and B. Zhang. 2011. Analysis of influence factors of agricultural socialization service demand - based on sampling survey of 214 households of 74 villages in Shaanxi province. Rural Economy 6: 83-87.

Li, Q., W.J. Yang and K. Li. 2018. Role of social learning in the diffusion of environmentally-friendly agricultural technology in China. Sustainability 10: 1527.

Li, R.Y. 2015. Agricultural social service demand priority from farmers - based on micro survey data analysis of 15 provinces of China. Journal of Northwest A\&F University 1: 86-94.

Li, X.G. and C.Y. Jiang. 2015. Farmers' availability for agricultural productive services and influencing factors based on 1121 peasant families. Agricultural Economics and Management 4: 21-29.

Liu, E.M. 2013. Time to change what to sow: risk preferences and technology adoption decisions of cotton farmers in China. The Review of Economics and Statistics 95(4): 1386.

Liu, H.J, Z.D. Jiang and J.J. Wang. 2014. Affecting factors of agriculture follow-up industry in plateau district: the hierarchical linear analysis based on the household survey data of Ansai county. Economic Geography 2(34): 125-130.

Liu, L. 2015. On the supply priority of rural public services and the demand classification with the KANO model. Finance and Trade Research 6: 39-46.

Luo, X.F., X.X. Xiang and R.R. Li. 2016. What is the most urgent need of agricultural socialized service for large farmers. Journal of Agrotechnical Economics 5: 4-12.

Luor, T., H.P. Lu, K.M. Chien and T.C. Wu. 2015. Contribution to quality research: a literature review of Kano's model from 1998 to 2012. Total Quality Management \& Business Excellence 3-4: 234-247.

Mariwah, S. and J.-O. Drangert. 2011. Community perceptions of human excreta as fertilizer in peri-urban agriculture in Ghana. Waste Management \& Research 29(8): 815-822.

Mikulić, J. and D. Prebežac. 2011. A critical review of techniques for classifying quality attributes in the Kano model. Managing Service Quality 21(1): 46-66.

Mills, J., P. Gaskell, J. Ingram, J. Dwyer, M. Reed and C. Short. 2017. Engaging farmers in environmental management through a better understanding of behaviour. Agriculture and Human Values 34(2): 283-299.

Mugonola, B., J. Deckers, J. Poesen, M. Isabirye and E. Mathijs. 2013. Adoption of soil and water conservation technologies in the Rwizi catchment of south western Uganda. International Journal of Agricultural Sustainability 11(3): 264-281.

Pan, Q.C., L.X. Zhang, C. Zhang and H.Q. Li. 2016. Evaluation of functional service requirements of academic journals website based on the kano model. Chinese Journal of Scientific and Technical Periodicals 6: 617-623.

Pang, X.P. 2006. Comparison and analysis of the structure differences of supply and demand of agricultural socialized services: based on the investigation and consideration of the present situation of supply and demand of agricultural socialized services. Journal of Agrotechnical Economics 4: 35-40.

Rachael, K.E. 2012. Meta-analysis of the relationship between coworker social support and burnout using a two-level hierarchical linear model. Western Journal of Nursing Research 8(34): 1062-1063. 
Raju, G., W.C. Huang and S.R. Bahadur. 2015. Factors affecting adoption of improved rice varieties among rural farm households in Central Nepal. Rice Science 22(1): 35-43.

Rasmussem, J.J., P. Wiberg-Larsen, A. Baattrup-Pedersen, N. Cedergreen, U.S. McKnight, J. Kreuger, D. Jacobsen, E.A. Kristensen and N. Friberg. 2015. The legacy of pesticide pollution: an overlooked factor in current risk assessments of freshwater systems. Water Research 84: 25-32.

Reimer, A.R., W.A. Thompson and L.S. Prokopy. 2012. The multi-dimensional nature of environmental attitudes among farmers in Indiana: implications for conservation adoption. Agriculture and Human Values 29: 29-40.

Rocconi, L.M. 2013. Analyzing multilevel data: comparing findings from hierarchical linear modeling and ordinary least squares regression. Higher Education 4(66): 439-461.

Soukup, P. 2006. Why use hierarchical linear models. Sociologicky Casopis Czech Sociological Review 5(42): 987-1012.

Sun, J. and Z.H. Huang. 2009. An empirical study on farmers' agricultural service channel choice behavior and influencing factors. Journal of Agrotechnical Economics 1: 37-74.

Tan, C.F., L. Zhang and W.H. Tian. 2017. Factors affecting the willingness to adopt farmland recycling production technology - based on a survey in Hexi Corridor. Journal of Arid Land Resources and Environment 8: 33-37.

Teo, T. 2011. Basic concepts of hierarchical linear modelling (HLM) for educational technology research. British Journal of Educational Technology 3(42): E51-E53.

Teshome, A., J. de Graaff and M. Kassie. 2016. Household-level determinants of soil and water conservation adoption phases: evidence from North-Western Ethiopian Highlands. Environmental Management 57(3): 620-636.

Tontini, G. 2007. Integrating the Kano model and QFD for designing new products. Total Quality Management \& Business Excellence 6: 599-612.

Walters, R.W. and L. Hoffman. 2017. Applying the hierarchical linear model to longitudinal data. Higher Education 3(29): 666-701.

Wang, Y., R.Y. Ying Y.G. and Zhang. 2007. A study on the priority of farmers' demand for agricultural technology services in Jiangsu Province. Forum on Science and Technology in China 11: 123-126.

Wang, Z., H. Liu and Z.L. Cao. 2015. Analysis of the demand for agricultural socialization services: based on a sample survey of 191 farmers in Chongqing. Journal of Agrotechnical Economics 9: 17-26.

Xia, B. and N.H. Jiang. 2016. Research on the supply side reform of agricultural socialized service for large grain farmers - based on the survey of 264 sample farmers in Yangzhou. Finance and Accounting Monthly 35: 66-70.

Xiong, Y. 2010. An empirical analysis of farmers' demand for agricultural socialization services - based on a survey of 176 sample farmers in Chengdu. Rural Economy 3: 93-96.

Xu, B. and R.Y. Ying. 2015. An empirical study on farmers' satisfaction with agricultural social service based on principal-agent theory - a case of regional pest control program in China. China Soft Science 5: $38-76$.

Xu, Q.L., R.J. Jiao, X. Yang and M. Helander. 2009. An analytical Kano model for customer need analysis. Design Studies 30: 87-110.

Yang, W.J. Research on economic development of rice industry (2017). Zhejiang University Press, Hangzhou, China.

Yang, X., S. Fang, C.L. Lant and X. Luo. 2012. Overfertilization in the economically developed and ecologically critical Lake Tai region, China. Human Ecology 40(6): 957-964.

Ye, H. 2015. Influential factors of farmers' demands for agricultural science and technology in China. Technological Forecasting and Social Change 100: 249-254.

Yin, S.J., R. Li, L.H. Wu and X.J. Chen. 2018. Introduction to 2018 China development report on food safety. Peking University Press, Beijing, China.

Yueh, H.P., T.L. Chen and L.A. Chiu. 2013. Exploring factors affecting learner's perception of learning information and communication technology: a HLM analysis of a national farmers' training program in Taiwan. Educational Technology \& Society 2(16): 231-242. 
Zhang, L., Q. Guo, J.B. Zhan and Q.M. Tong. 2017. Farmer's demand for productive public services in response to climate disasters and its determinants: evidence from one thousand households of one hundred villages in ten counties of Hubei Province. China Rural Survey 3: 102-116.

Zhang, M.M. and Y.J. Li. 2014. The reason of farmers' passive trust to agricultural materials retailers: a case study from the perspective of social network embeddedness. China Rural Survey 5: 25-37.

Zhang, X.M. and C.Y. Jiang. 2015. Supply evaluation and demand willingness of different types of farmers for agricultural productive services. Research on Economics and Management 8: 70-76.

Zhang, Y.G. and R.Y. Ying. 2007. An analysis of the priority and influencing factor s of farmer s' demand for technological services - an empirical study on planting farmer s of Jiangsu Province. Jiangsu Social Science 3: 65-71.

Zhao, M. and D.R. Roy. 2009. A multi-attribute model of web site interactivity and customer satisfaction: an application of the Kano model. Managing Service Quality 3: 286-307.

Zhou, J.H., H.Y. Yang and Z.C. He. 2012. The limitation of rural households' adoption of the resource-efficient and environment-friendly technologies and the practice breakthrough. China Rural Survey 2: 37-43.

Zhu, H.J. and Z.H. Tian. 2012. Analysis on dilemma of low carbon agriculture technology in rice production. China Agricultural University Journal of Social Sciences Edition 4: 153-160.

Zhu, M., Z.H. Hong, L.N. Luo, S.Y. Tang, Y.L. Wu and X.R. Li. 2015 Analysis on factors influencing rice farmers' adoption of agricultural techniques based on Probit ISM model - a case study of 320 rice farmers in Hubei Province. Journal of Applied Statistics and Management 1: 11-23.

Zhuang, L.J., M.Y. He and J. Zhang. 2011. Analysis on the willingness and influencing factors of agricultural productive service demand - taking the investigation of 450 litchi producers in Guangdong Province as an example. Chinese Rural Economy 3: 70-78. 
$\stackrel{0}{0}$
$\dot{\infty}$
$\infty$ 